\title{
EVALUASI PENGGUNAAN TEKNOLOGI MEDIA SOSIAL DALAM MEMPERLUAS BISNIS PEMASARAN ONLINE
}

\section{EVALUATION OF THE USE OF SOCIAL MEDIA TECHNOLOGY IN EXPANDING ONLINE MARKETING BUSINESSES}

\author{
Sandy Kosasi ${ }^{1}$ \\ STMIK Pontianak Jurusan Sistem Informasi ${ }^{1}$ \\ e-mail: sandykosasi@yahoo.co.id \\ Diterima: 8 Juni 2017/ Disetujui : 15 Juni 2017
}

\begin{abstract}
This research aimed to evaluate the use of information technology governance in expanding online marketing businesses. Cosmetics were researched products. AI (Acquire and Implement) and ME (Monitor and Evaluate) under COBIT 4.1 Framework were concerned. Respondents working in 35 companies and using social media technology for online marketing businesses were surveyed. This research also aimed to find out the gap values of the use of social media technology of online marketing businesses based on AI and ME Domains. Implications on managerial aspects and information technology governance show that there are relationships among information technology processes of AI, ME, and others. Research results show that the highest gap values (0.544 and 0.465$)$ are at AI4 and ME4 Processes. These values are also at the lowest maturity levels (2.456 and 2.535). Moreover, AI4 is related to input control objectives (PO10, AI1, AI2, AI3, AI7, and DS7) and output control objectives (AI7, DS4, DS8, DS9, DS11, DS13, and DS7). On the other hand, ME4 is related to input control objectives (PO4, PO5, PO9, ME2, and ME3) and output control objectives (PO4, PO1, ME1, PO5, PO1, and PO9).
\end{abstract}

Keywords : Information Technology Governance, Acquired and Implement, Monitor and Evaluate, Online Marketing Businesses, COBIT 4.1

\begin{abstract}
ABSTRAK
Penelitian ini untuk menilai penggunaan tata kelola teknologi informasi dalam memperluas bisnis pemasaran online untuk produk kosmetik dari sisi domain AI (Acquire and Implement) dan ME (Monitor and Evaluate) dengan kerangka kerja COBIT 4.1. Bentuk penelitian survei dengan jumlah responden 35 perusahaan yang sudah menggunakan teknologi media sosial dalam bisnis pemasaran online. Tujuan penelitian untuk mengetahui nilai kesenjangan penggunaan teknologi media sosial dalam bisnis pemasaran online dari sisi domain AI dan ME. Hubungannya dengan Implikasi pada aspek manajerial dan rekomendasi tata kelola teknologi informasi yang memperlihatkan hubungan keterkaitan proses AI dan ME dengan proses teknologi informasi lainnya. Hasil penelitian memperlihatkan nilai kesenjangan tertinggi pada proses AI4 dan ME4 yaitu 0,544 dan 0,465 dan merupakan tingkat kematangan terendah dengan nilai 2,456 dan 2,535. Tata kelola teknologi informasi pada proses AI4 memiliki keterkaitan hubungan antara objektif kontrol input terdiri dari PO10, AI1, AI2, AI3, AI7, dan DS7. Sementara objektif kontrol output terdiri dari AI7, DS4, DS8, DS9, DS11, DS13; DS7; and DS7. Selanjutnya untuk proses ME4 memiliki keterkaitan hubungan antara objektif kontrol input terdiri dari objektif kontrol input terdiri dari PO4, PO5, PO9, ME2, dan ME3. Sementara objektif kontrol output terdiri dari PO4, PO1 dan ME1, PO5, PO1, dan PO9.
\end{abstract}


Kata kunci: Tata Kelola Teknologi Informasi, Acquired and Implement, Monitor and Evaluate, Bisnis Pemasran Online, COBIT 4.1

\section{PENDAHULUAN}

Media sosial kini bukan hanya situs internet semata, namun lebih dari pada itu. Media sosial saat ini sudah menjadi ruang publik. Media sosial telah menjadi salah satu strategi pemasaran yang sangat penting dalam era transformasi bisnis digital. Pesatnya kemajuan teknologi bergerak dengan didukung oleh fasilitas untuk mengakses internet yang semakin baik dapat memberikan peluang dalam memperluas pangsa pasar secara global [1]. Penggunaan media sosial di tengah teknologi yang terus berkembang telah memberikan implikasi yang sangat signifikan dan positif dalam berbagai sektor bisnis. Media sosial sudah menjadi bagian yang inheren dengan kehidupan dan kelangsungan kinerja bisnis perusahaan. Melalui kanal media sosial seperti Twitter, Facebook, Instagram, dan Linkedln relatif memberikan kemudahan melakukan promosi [2] atau menjangkau target pemasaran produk secara lebih luas. Media sosial juga memungkinkan promosi dilakukan melalui pemasaran viral atau langsung berhubungan dengan calon konsumennya. Selain itu, penggunaan teknologi media sosial telah menjadikan siklus hidup produk menjadi semakin pendek dengan keberagaman inovasi yang terus bermunculan dalam memperebutkan ceruk-ceruk pasar [3].

Penggunaan media sosial menjadi semakin penting sehubungan dengan hasil publikasi dari Internet world stats (www.internetworldstats.com) yang memperlihatkan lebih dari 30 persen populasi dunia mengakses internet. Jumlahnya diperkirakan lebih dari 2,2 miliar orang. Sebanyak 82 persen dari populasi internet tersebut adalah berusia lebih dari 15 tahun dan terkoneksi dengan situs-situs jejaring sosial. Hasil riset APJII (Asosiasi Penyelenggara Jasa Internet Indonesia) untuk tahun 2014 secara signifikan menunjukkan pengguna media sosial menduduki peringkat tertinggi. Posisi kedua ada pada media pencarian informasi, disusul dengan percakapan/pesan singkat, pencarian berita, video, dan email. Dari tujuh lokasi penjualan online (forum jual beli, media sosial, mailing list, blog, domain, messenger dan komunitas online), media sosial adalah tempat yang paling banyak digunakan oleh pengguna internet di Indonesia $(64,9 \%)$ [4].

Berdasarkan hasil survei 2016 yang dirilis oleh Polling Indonesia dan APJII memperlihatkan penetrasi pengguna internet Indonesia semakin berkembang dan sudah mencapai 132,7 juta dari total populasi penduduk Indonesia 256,2 juta orang. Jenis konten internet yang paling banyak diakses adalah media sosial sebanyak $97,4 \%$ atau 129,2 juta orang terutama melalui facebook (54\%), instagram (15\%), Youtube (11\%), Google+ $(6 \%)$, Twitter $(5,5 \%)$, dan Linkedin $(0,6 \%)$. Sementara untuk kebutuhan bisnis melalui perdagangan elektronik sudah mencapai sekitar 8,5\% atau 10,4 juta orang [5]. Kenyataan ini memberikan peluang besar bagi komunitas bisnis di Indonesia. Perubahan pergeseran paradigma pemasaran, dari pemasaran tradisional (offline) ke pemasaran modern (online). Media sosial merupakan perkembangan teknologi informasi yang relatif baru namun berpotensi membawa revolusi atau perubahan besar dalam proses bisnis di masa sekarang dan mendatang.

Media sosial dapat diartikan sebagai kelompok aplikasi berbasis internet yang dibangun di atas fondasi ideologi dan teknologi Web 2.0 dan memungkinkan penciptaan dan pertukaran konten dengan pengguna secara luas [6]. Semua tentang jaringan dan jaringan dengan cara mengemban kepercayaan di antara pihak-pihak dan masyarakat yang terlibat dan memungkinkan pengguna untuk saling berbagi konten [7]. Melihat pelanggan sebagai kunci penggunaan media sosial [8], mendefinisikan sebagai komponen teknologi komunikasi, transaksi dan membangun hubungan fungsi bisnis dengan memanfaatkan jaringan pelanggan dan prospek membangun mitra kerja secara global [9]. Pasar menjadi lebih transparan, mudah menelusuri berbagai saluran yang tersedia dalam membangun hubungan dengan pelanggan. Meningkatkan kolaborasi berbasis kolektivisme yang dapat memperkuat kohesi organisasi untuk menjadi lebih lincah dalam mencapai tujuan dan sasaran bisnis. Mendorong pertumbuhan ekonomi, mengurangi persediaan barang, meningkatkan efisiensi dan efektivitas, menghemat waktu operasional, peluang baru dalam mengakses pasar sasaran, meningkatkan omset penjualan, perluasan ceruk pasar dan segmentasi pelanggan, kemudahan mencari produk/jasa, dan meningkatkan pendapatan [10]. 
Keberhasilan bisnis pemasaran online sangat bergantung kepada kesiapan teknologi aplikasi media sosialnya [11] dan menumbuhkan sifat komunikasi interaktif melalui jejaring media sosial [12]. Kondisi ini penting mengingat dalam memenuhi kebutuhan produk dan jasa tidak lagi hanya fokus kepada kualitas namun lebih kepada nilai-nilai estetika dari produk dan jasa [13]. Media sosial telah mengubah cara dan perilaku berkomunikasi, berkolaborasi, mengkonsumsi, dan menciptakan nilainilai. Memiliki kemampuan membangun hubungan dan membina interaksi secara personal. Meningkatkan komunikasi dalam dan di luar organisasi melalui kolaborasi pengetahuan untuk mencapai dan meningkatkan aksesibilitas informasi. Konsumen memiliki keleluwasan membuat pilihan sebelum melakukan transaksi jual beli secara online melalui komunikasi dua arah. Keinginan berpartisipasi, berinteraksi, dan menciptakan nilai bagi konsumen membuat media sosial semakin menjadi pertimbangan utama dalam merumuskan aktivitas dan menjalankan bisnis pemasaran online. Pernyataan ini didukung oleh McKinsey [14], dimana hasil risetnya memperlihatkan banyak perusahaan berhasil memperoleh keuntungan dan meningkatkan kinerja bisnisnya melalui teknologi media sosial.

Melalui media sosial, orang-orang Dapat membuat, berbagi, dan bertukar informasi dalam komunitas virtual [15]. Perkembangan ini telah membentuk hubungan orang-orang dengan platform media sosial yang berbeda-beda [16]. Hari ini, manfaat berpartisipasi dalam media sosial tidak hanya melibatkan komunikasi sosial, namun juga membangun reputasi dan hubungan dalam peluang karir, dan/atau menghasilkan pendapatan moneter langsung [17]. Media sosial mendorong serangkaian model baru untuk berbagai jenis bisnis yang menantang proses bisnis dan operasi tradisional [18]. Perbedaan yang menonjol adalah bahwa kustomisasi massal satu-ke-satu menjadi norma transaksi bisnis, menggantikan model promosi pemasaran satu lawan satu [19]. Media sosial juga dapat berfungsi sebagai alat yang memfasilitasi aktivitas intra daninter-organisasi antara teman sebaya, pelanggan, mitra bisnis, dan organisasi; Seperti pengembangan produk kolaboratif [20, 21], implementasi dialog perusahaan di Lembaga keuangan [22], dan pembelajaran kolaboratif dan kreativitas [23].

Namun menerapkan media sosial membutuhkan jaminan kelancaran dan penyediaan layanan teknologi informasi yang handal dari sisi tingkat kematangannya. Pengukuran tingkat kematangan dapat ditinjau dari kebutuhan melakukan modifikasi/solusi sistem; menetapkan prosedur penjadwalan dan pemeliharaan infrastruktur; melakukan update prosedur manual, verifikasi sistem baru, dan mendokumentasikan perubahan penerapan sistem; monitoring dan evaluasi pengelolaan teknologi informasi secara rutin dan berkelanjutan; proses perawatan dan pemeliharaan keamanan data/informasi secara menyeluruh. Melalui proses pemantauan dan evaluasi dapat memberikan nilainilai kontribusi untuk pengendalian efisiensi kontrol internal dan kebutuhan eksternal, penciptaan transparansi dan penilaian kinerja teknologi informasi, percepatan pembuatan laporan dan pendayagunaan sumberdaya manusia [24].

Evaluasi kematangan tata kelola teknologi informasi memiliki peran penting untuk menjamin pencapaian tujuan bisnis dan mencegah resiko kegagalan dan ketidaksesuaian proses bisnis. Tata kelola teknologi informasi penting menyediakan jaminan untuk mencapai tujuan bisnis dan mencegah resiko kegagalan/ketidaksesuaian proses bisnis dengan memperhatikan semua kepatutan pengelolaan data dan informasi [24]. Tata kelola teknologi informasi didefinisikan sebagai suatu bagian integral dari tata kelola organisasi yang terdiri atas kepemimpinan, struktur dan proses organisasional yang memastikan bahwa teknologi informasi organisasi berlanjut serta meningkatkan tujuan dan strategi organisasi. Tata kelola teknologi informasi melakukan penspesifikasian hak keputusan dan rerangka akuntabilitas untuk mengarahkan perilaku yang diinginkan dalam penggunaan teknologi informasi [25].

Sejauh ini belum ada penelitian yang secara spesifik melakukan evaluasi mengenai tingkat kematangan dari tata kelola teknologi informasinya. Penelitian sosial media lebih kearah sebagai salah satu saluran utama melakukan komunikasi menjalin hubungan dan kolaborasi dengan orang lain di seluruh dunia [26]. Pertumbuhan yang berkelanjutan dan keberhasilan perusahaan identik dengan penggunaan media sosial. Media sosial telah menjadi aspek penting dari strategi bisnis, pengenalan merek, peningkatan pendapatan dan peningkatan kepuasan pelanggan [27]. Media sosial telah mengubah struktur kekuasaan di pasar dan sebagai strategi mengakumulasi kebutuhan pelanggan dan intelijen pasar sebagai saluran pemasaran langsung [28]. Bisnis online bergantung kepada ketersediaan dan kehandalan tata kelola teknologi informasinya. Mengingat dalam bisnis online 
semua aktivitas dan transaksi sudah melalui mekanisme pengelolaan secara digital melalui teknologi informasi [29]. Kenyataan ini membutuhkan proses untuk mengetahui tingkat kematangan tata kelola teknologi informasi untuk dua aspek utama. Pertama proses pengadaan dan penerapan perangkat solusi sistem dan infrastruktur teknologi informasi. Kedua proses ketersediaan dukungan dan layanan teknologi informasi saat ini dan peningkatannya di masa mendatang [30].

Permasalahan dalam penelitian ini menitikberatkan lebih kepada domain AI (Acquire and Implement) dan ME (Monitor and Evaluate) ini yakni (a) bagaimana nilai kesenjangan tingkat kematangan tata kelola teknologi informasi media sosial saat ini dengan yang diharapkan dalam bisnis pemasaran online? (b) bagaimana implikasi bagi pihak manajerial menggunakan teknologi media sosial dalam bisnis pemasaran online? (c) bagaimana model rekomendasi dari tata kelola teknologi informasi untuk menjamin agar penggunaan teknologi media sosial dapat mencapai tujuan dari bisnis pemasaran online?. Adapun yang menjadi tujuan dari penelitian adalah untuk mengetahui nilai kesenjangan antara tingkat kematangan saat ini dengan tingkat kematangan yang diharapkan dari tata kelola teknologi informasi untuk penggunaan teknologi media sosial dalam bisnis pemasaran online dari sisi domain AI dan ME. Selanjutnya memaparkan hasil analisis kesenjangan dalam kaitannya dengan implikasi pada aspek manajerial dan merekomendasikan tata kelola teknologi informasi yang memperlihatkan hubungan keterkaitan proses $\mathrm{AI}$ dan ME dengan proses teknologi informasi lainnya.

\section{METODE PENELITIAN}

Penelitian berbentuk survei dan responden penelitian sebanyak 35 perusahaan yang sudah menggunakan teknologi media sosial dalam memperluas aktivitas bisnis pemasaran online khusus produk kosmetik yang berada di Kota Pontianak. Pengambilan sampel dengan teknik purposive sampling. Instrumen penelitian dengan menggunakan sebaran angket dan dikelompokkan berdasarkan masing-masing proses. Setiap proses dibagi menurut tingkatannya dan setiap tingkat di sajikan berdasarkan butir-butir pertanyaan dengan menggunakan skala Guttman. Setelah semua hasil kuesioner dimasukkan dalam tabel dan kemudian baru dihitung tingkat kematangan dari tiap-tiap proses untuk setiap responden. Hasil tingkat kematangan tiap proses dari 35 responden kemudian dicari rata-ratanya, dan hasil rata-rata tersebut akan menjadi nilai tingkat kematangan tiap proses teknologi informasi. Untuk pengolahan data responden diawali dengan menghitung tingkat kematangan. Kemudian mengolah tingkat kematangan masing-masing proses bisnis. Selanjutnya menghitung agregasi tingkat kematangan melalui rata-rata aritmatik. Terakhir hasil agregasi disajikan dalam bentuk tabel dan grafik radar menggunakan perangkat lunak Microsoft Excel.

Untuk mengevaluasi penggunaan teknologi media sosial menggunakan kerangka kerja COBIT 4.1 (Control Objectives for Information and Related Technology). COBIT 4.1 dapat diartikan sebagai tujuan pengendalian untuk informasi dan teknologi terkait dan merupakan standar untuk pengendalian terhadap teknologi informasi. Kerangka kerja COBIT 4.1 memiliki empat domain utama, yaitu PO (Plan and Organize), AI (Acquire and Implement), DS (Deliver and Support), dan ME (Monitor and Evaluate) [31]. Khusus dalam penelitian ini hanya difokuskan kepada tingkat kematangan domain AI dan ME. Penentuan domain sehubungan dengan penggunaan teknologi media sosialnya. Tingkat kematangan AI mencerminkan kesiapan menerapkan teknologi informasi untuk memperlihatkan kesesuaian sistem perubahan dan pemeliharaan dari sistem yang ada, dan selaras dengan sasaran bisnis. Selain itu untuk memberikan kepastian solusi otomatis dan sistem pemeliharaan sumberdaya teknologi informasi bahwa telah memenuhi standarisasi kebutuhan bisnis [31]. Sementara untuk tingkat kematangan domain ME mencerminkan kesiapan pengontrolan proses teknologi informasi untuk menjaga kualitas dan pemenuhannya. Domain ini berhubungan dengan kinerja manajemen, kontrol internal, pemenuhan terhadap aturan serta menyediakan tata kelola teknologi informasi [31].

Proses teknologi informasi dalam domain AI, terdiri dari: AI1 (Mengidentifikasikan solusi otomatis), AI2 (Memperoleh dan memelihara software aplikasi), AI3 (Memperoleh dan memelihara infrastruktur teknologi), AI4 (Memungkinkan operasional dan penggunaan), AI5 (Memenuhi sumber daya teknologi informasi), AI6 (Mengelola perubahan), AI7 (Instalasi dan akreditasi solusi beserta perubahannya) [24]. Proses teknologi informasi untuk domain ME, terdiri dari: ME1 (Mengawasi dan mengevaluasi kinerja teknologi informasi), ME2 (Mengawasi dan mengevaluasi kontrol internal), 
ME3 (Memastikan pemenuhan terhadap kebutuhan eksternal), ME4 (Menyediakan tata kelola teknologi informasi) [31,32].

Kemudian langkah selanjutnya adalah untuk menilai dan melakukan analisis tingkat kematangan teknologi informasi akan berbeda di tiap proses bisnis teknologi informasi dengan masing-masing kriteria pemenuhannya. Perhitungan nilai index kematangan untuk masing-masing objektif hasil penelitian dengan rumus: Nilai Index $=\left\{\sum\right.$ (jumlah jawaban $\mathrm{x}$ nilai kematangan): (jumlah pertanyaan $\mathrm{x}$ jumlah responden) $\}$, dan skala pembulatan indeks bagi pemetaan ke tingkat model kematangan. Tabel 1 menunjukkan skala pembulatan indeks untuk setiap tingkatan model kematangan mulai dari tingkat 0 (nol/non-existent) hingga tingkat 5 (optimised) [32].

Tabel 1. Skala Pembulatan Indeks

\begin{tabular}{|l|l|}
\hline Skala & Tingkat Model Kedewasaan (Maturity) \\
\hline $4,51-5,00$ & 5 - Dioptimalisasi (Optimised) \\
\hline $3,51-4,50$ & 4 - Diatur (Managed and Measurable) \\
\hline $2,51-3,50$ & 3 - Ditetapkan (Define) \\
\hline $1,51-2,50$ & 2 - Dapat diulang (Repeatable but intuitive) \\
\hline $0,51-1,50$ & 1 - Inisialisasi (Initial/Ad Hoc) \\
\hline $0,00-0,50$ & 0 - Tidak Ada (Non-Existent) \\
\hline
\end{tabular}

Nilai pengukuran tingkat kematangan memberikan identifikasi sejauhmana perusahaan telah memenuhi standar pengelolaan proses teknologi informasi. Gambar 1 memperlihatkan grafik interval tingkat kematangan memiliki tingkatan pengelompokkan kapabilitas pengelolaan proses teknologi informasi dari tingkat 0 (nol/non-existent) hingga tingkat 5 (optimised) dalam bentuk grafis. Tabel 2 menunjukkan tingkat dan deskripsi kriteria kematangan dengan tujuan memberikan kemudahan untuk memahami secara ringkas dari setiap tingkatan bagi pihak manajemen dan pemangku kepentingan melalui deskripsi dari masing-masing tingkat kematangan secara umum [32].

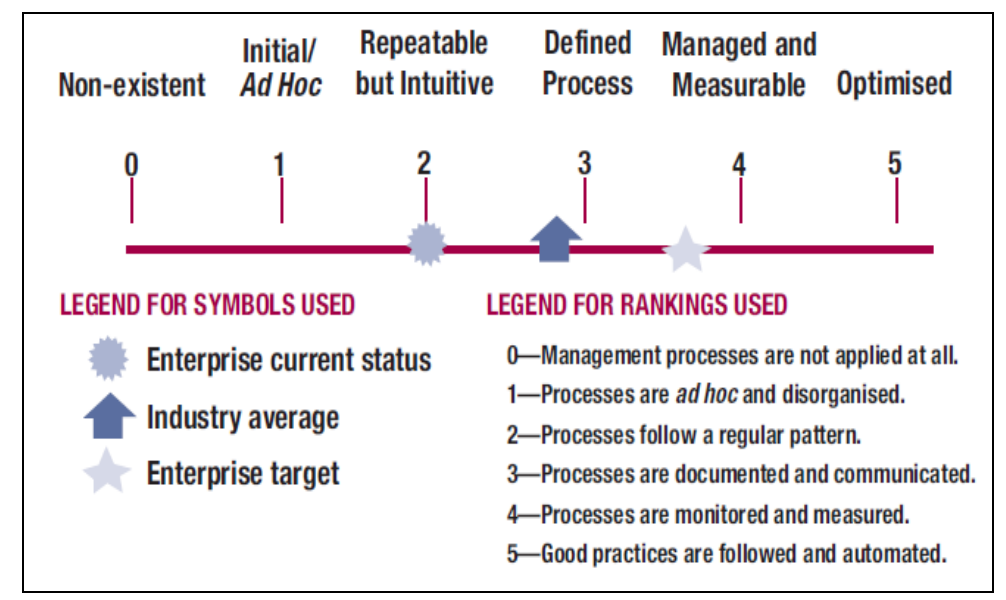

Gambar 1. Grafik Interval Tingkat Kematangan

Hasil penilaian tingkat kematangan dapat dijadikan sebagai bahan pertimbangan dalam penentuan kriteria tersebut. Peningkatan tingkat kematangan bukan dimaksudkan bahwa pemenuhan di tingkat bawah akan dapat memungkinkan naik ke tingkat yang lebih tinggi, dan diidentifikasikan sebagai pemenuhan terhadap beberapa kriteria kematangan dalam beberapa tingkat walaupun untuk proses yang sama. Perolehan dari setiap nilai tingkat kematangan ini sangat penting karena dapat menjadi ukuran indikator dalam mencapai tujuan dan kinerja dari setiap proses teknologi informasi. Setiap tingkatan mewakili inti proses yang berbeda-beda sesuai pencapaian dari setiap skala interval masing-masing [32]. 
Tabel 2. Tingkat dan Deskripsi Kriteria Kematangan

\begin{tabular}{|c|c|}
\hline Tingkat & Deskripsi Kriteria Kematangan \\
\hline $\begin{array}{c}0 \\
\text { Non existent }\end{array}$ & $\begin{array}{l}\text { Kekurangan yang menyeluruh terhadap proses apapun yang dapat } \\
\text { dikenali. Perusahaan bahkan tidak mengetahui bahwa terdapat } \\
\text { permasalahan-permasalahan yang harus diatasi. }\end{array}$ \\
\hline $\begin{array}{c}1 \\
\text { Initial/ } \\
\text { Ad Hoc }\end{array}$ & $\begin{array}{l}\text { Terdapat bukti bahwa perusahaan mengetahui adanya permasalahan } \\
\text { yang harus diatasi. Bagaimanapun juga tidak terdapat proses standar, } \\
\text { namun menggunakan pendekatan ad hoc yang cenderung diberlakukan } \\
\text { secara individu atau berbasis per kasus. Secara umum pendekatan } \\
\text { kepada pengelolaan proses tidak terorganisasi. }\end{array}$ \\
\hline $\begin{array}{c}2 \\
\text { Repeatable but } \\
\text { intuitive }\end{array}$ & $\begin{array}{l}\text { Proses dikembangkan ke dalam tahapan yang prosedur serupa diikuti } \\
\text { oleh pihak-pihak yang berbeda untuk pekerjaan yang sama. Tidak } \\
\text { terdapat pelatihan formal atau pengomunikasian prosedur standar dan } \\
\text { tanggung jawab diserahkan kepada individu masing-masing. Terdapat } \\
\text { kepercayaan yang tinggi terhadap pengetahuan individu sehingga } \\
\text { kemungkinan kesalahan besar dapat terjadi. }\end{array}$ \\
\hline $\begin{array}{c}3 \\
\text { Defined }\end{array}$ & $\begin{array}{l}\text { Prosedur distandarisasi dan didokumentasikan kemudian } \\
\text { dikomunikasikan melalui pelatihan. Selanjutnya diamanatkan proses- } \\
\text { proses tersebut harus diikuti. Namun penyimpangan tidak mungkin dapat } \\
\text { terdeteksi. Prosedur sendiri tidak lengkap namun sudah memformalkan } \\
\text { praktek yang berjalan. }\end{array}$ \\
\hline $\begin{array}{c}4 \\
\text { Managed and } \\
\text { Measurable }\end{array}$ & $\begin{array}{l}\text { Manajemen mengawasi dan mengukur kepatutan terhadap prosedur dan } \\
\text { mengambil tindakan jika proses tidak dapat dikerjakan secara efektif. } \\
\text { Proses berada di bawah peningkatan yang konstan dan penyediaan } \\
\text { praktek yang baik. Otomatisasi dan perangkat digunakan dalam batasan } \\
\text { tertentu. }\end{array}$ \\
\hline $\begin{array}{l}5 \\
\text { Optimised }\end{array}$ & $\begin{array}{l}\text { Proses telah dipilih ke dalam tingkat praktek yang baik, berdasarkan } \\
\text { hasil dari perbaikan berkelanjutan dan pemodelan kedewasaan dengan } \\
\text { perusahaan lain. Teknologi informasi digunakan sebagai cara terintegrasi } \\
\text { untuk mengotomatisasi alur kerja, penyediaan alat untuk peningkatan } \\
\text { kualitas dan efektivitas serta membuat perusahaan cepat beradaptasi. }\end{array}$ \\
\hline
\end{tabular}

\section{HASIL DAN PEMBAHASAN}

Melalui hasil pengukuran tingkat kematangan tata kelola teknologi informasi dapat diketahui penilaian tentang kondisi saat ini untuk domain AI dan ME mengenai penggunaan teknologi media sosial dalam memperluas bisnis pemasaran online. Tabel 3 menunjukkan untuk tingkat kematangan terendah berada pada proses AI4 dengan nilai 2,456 dalam kaitannya dengan proses memungkinkan operasional dan penggunaan. Nilai ini masih dibawah interval 2,51 sehingga perlu segera ditindaklanjuti. Hal ini terjadi karena penerapan teknologi informasi pada bisnis pemasaran online di Kota Pontianak belum memiliki kejelasan pendefinisian mengenai kebutuhan operasional dan penggunaan yang baik, manual prosedur penggunaan belum secara spesifik dinyatakan dan dibuatkan sebuah standarisasi yang terstruktur, dan materi pelatihannya belum sepenuhnya dijabarkan dan dideskripsikan secara baik dan mudah untuk dipahami dan dilaksanakan sebagaimana mestinya sehingga dalam penerapannya tidak banyak dipahami oleh staf operasional. Secara rata-rata domain AI memiliki nilai 2,706, dan berada dalam skala dari 2,51 - 3,50. Artinya berada pada posisi ke 3 (ditetapkan/defined). Kriteria kematangannya memiliki deskripsi dimana prosedur sudah distandarisasi, didokumentasikan dan dikomunikasikan melalui pelatihan. Kemudian diamanatkan bahwa proses-proses tersebut harus diikuti. Namun penyimpangan tidak mungkin dapat terdeteksi. Prosedur tidak lengkap namun sudah memformalkan praktek yang berjalan. Gambar 2 
memperlihatkan grafik radar mengenai hasil evaluasi dari nilai tingkat kematangan saat ini dan nilai tingkat kematangan yang diharapkan pada domain AI.

Tabel 3. Perhitungan Tingkat Kematangan Domain AI

\begin{tabular}{|c|l|c|}
\hline Domain & \multicolumn{1}{|c|}{ Proses } & $\begin{array}{c}\text { Tingkat } \\
\text { Kematangan } \\
\text { Saat Ini }\end{array}$ \\
\hline AI1 & Mengidentifikasi solusi otomatis & 2,826 \\
\hline AI2 & Memperoleh dan memelihara perangkat lunak aplikasi & 2,655 \\
\hline AI3 & $\begin{array}{l}\text { Memperoleh dan memelihara infrastruktur teknologi } \\
\text { informasi }\end{array}$ & 2,935 \\
\hline AI4 & Memungkinkan operasional dan penggunaan & 2,456 \\
\hline AI5 & Menenuhi sumberdaya teknologi informasi & 2,796 \\
\hline AI6 & Mengelola perubahan & 2,742 \\
\hline AI7 & Instalasi dan akreditasi solusi beserta perubahannya & 2,535 \\
\hline & \multicolumn{1}{|c}{ Rata-Rata Domain } & $\mathbf{2 , 7 0 6}$ \\
\hline
\end{tabular}

Tabel 4 tingkat kematangan saat ini yang terendah dalam domain ME berada pada proses ME4 kaitannya dalam hal menyediakan tata keloa teknologi informasi dengan nilai tingkat kematangan 2,535. Secara rata-rata domain ME memiliki nilai 2,639, dan berada dalam skala dari $2,51-3,50$. Artinya berada pada posisi ke 3 (ditetapkan/defined). Hal ini terjadi karena sejauh ini bisnis pemasaran online belum memiliki suatu program pengendalian teknologi informasi internal yang efektif melalui pros2es pemantauan yang terdefinisi dengan baik. Proses yang harus mendapatkan perhatian mencakup pemantauan dan pelaporan kontrol, tinjauan hasil penilaian diri dan pihak ketiga. Selain itu, harus membangun suatu pengendalian internal agar memiliki jaminan mengenai operasi yang efektif dan efisien dan sesuai dengan hukum dan peraturan yang berlaku.

Tabel 4. Perhitungan Tingkat Kematangan Domain ME

\begin{tabular}{|c|l|c|}
\hline Domain & \multicolumn{1}{|c|}{ Proses } & $\begin{array}{c}\text { Tingkat } \\
\text { Kematangan } \\
\text { Saat Ini }\end{array}$ \\
\hline ME1 & Mengawasi dan mengevaluasi kinerja teknologi informasi & 2,755 \\
\hline ME2 & Mengawasi dan mengevaluasi kontrol internal & 2,579 \\
\hline ME3 & Memastikan pemenuhan terhadap kebutuhan eksternal & 2,687 \\
\hline ME4 & Menyediakan tata kelola teknologi informasi & 2,535 \\
\hline \multicolumn{2}{r}{ Rata-Rata Domain } & $\mathbf{2 , 6 3 9}$ \\
\hline
\end{tabular}


Berdasarkan pemantauan belum memiliki kerangka kerja tata kelola yang efektif dalam mendefinisikan struktur organisasi, proses, kepemimpinan, peran dan tanggung jawab untuk memastikan bahwa investasi teknologi informasi dalam lingkungan bisnis pemasaran online harus selaras dan dilakukan sesuai dengan strategi dan tujuannya. Oleh karena itulah, pihak pimpinan harus dapat mengenali akan kebutuhan manajemen teknologi informasi secara regular melalui suatu jaminan kontrol yang baik. Penilaian kontrol internal teknologi informasi dilakukan sebagai bagian dari audit keuangan yang merefleksikan kebutuhan akan fungsi layanan informasi dan semua harus dilakukan secara proaktif dan memiliki kontribusi perencanaan yang terstruktur berdasarkan keputusan semua individu yang terlibat melalui tools dan matriks. Gambar 3 memperlihatkan grafik radar mengenai hasil evaluasi dari nilai tingkat kematangan saat ini dan nilai tingkat kematangan yang diharapkan pada penggunaan teknologi media sosial pada domain ME.

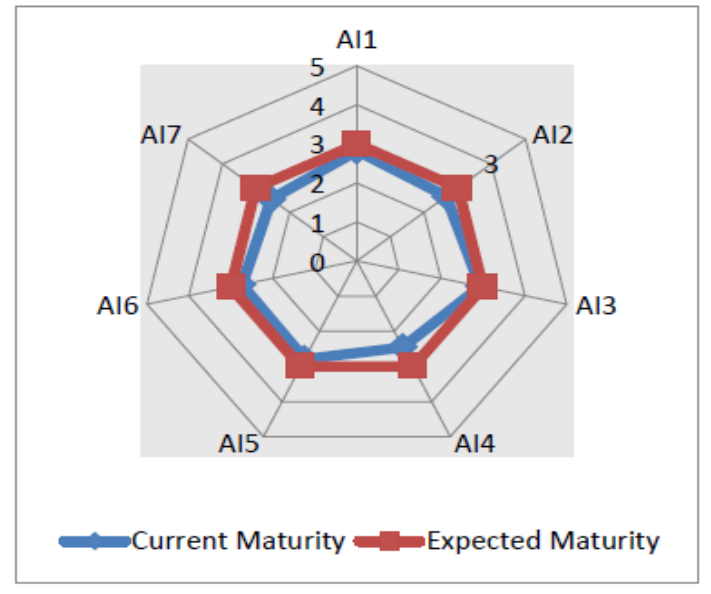

Gambar 2. Grafik Nilai Tingkat Kematangan Domain AI

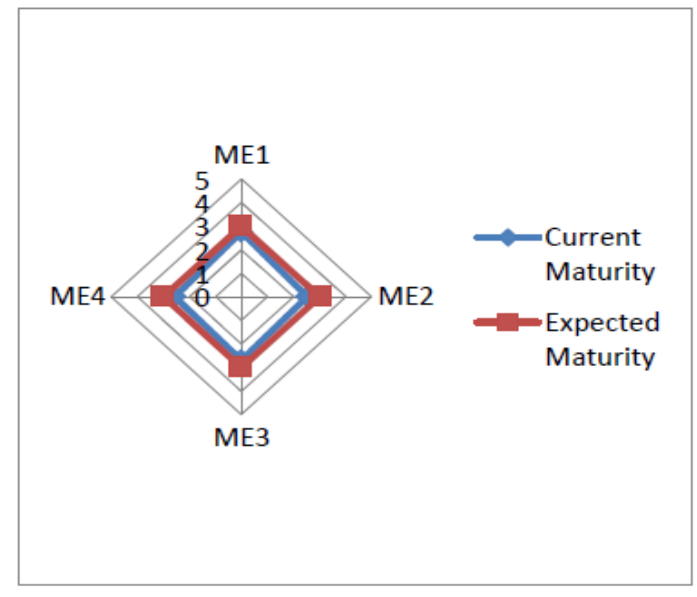

Gambar 3. Grafik Nilai Tingkat Kematangan Domain ME

Implikasi pada aspek manajerial memperlihatkan bahwa dengan tingkat kematangan terendah pada proses AI4 yang mewakili proses memungkinkan operasional dan penggunaan dengan nilai 2,456. Mendeskripsikan bahwa hal ini terjadi karena penerapan teknologi informasi dalam memperluas bisnis pemasaran online belum disertai dengan pendefinisian mengenai kebutuhan operasional dan tingkat layanan yang baik, manual prosedur penggunaan belum secara spesifik dinyatakan dan dibuatkan sebuah standarisasi yang terstruktur, dan materi pelatihannya belum sepenuhnya dijabarkan dan dideskripsikan secara baik dan mudah untuk dipahami dan dilaksanakan sebagaimana mestinya. Nilai kesenjangan tercatat 0,544 sebagai selisih dari tingkat kematangan ke 3 (ditetapkan/defined). Hal ini menandakan terdapat sejumlah kesenjangan yang harus dihilangkan agar dapat mencapai tingkat kematangan yang diinginkan. Hasil penelitian memperlihatkan dari semua rincian proses tersebut memiliki tipe prioritas yang berbeda dari sisi kebutuhan untuk segera dilakukan perbaikan dan yang menjadi prioritas utama. Proses tata kelola teknologi informasi yang menjadi prioritas utama yaitu pada proses AI4 (Memungkinkan operasional dan penggunaan). Selanjutnya untuk proses-proses lainnya berada pada tipe prioritas. Domain-domain yang merupakan prioritas untuk diperbaiki meliputi AI1, AI2, AI3, AI5, AI6 dan AI7. Hasil pengukuran mengindikasikan semakin baik hasil pengukuran kinerja atau semakin terpenuhinya ukuran kinerja yang didefinisikan, maka tingkat kematangan proses semakin tinggi juga. Pihak manajemen kemudian meninjau hasil pengukuran kinerja dan tingkat kematangan tiap proses dengan mengarahkan pemenuhan objektif kontrol dalam tiap proses teknologi informasi. Mendefinisikan kebijakan hingga prosedur, mengubah nilai indikator kinerja, penambahan objektif kontrol maupun penyempurnaan proses teknologi informasi hingga diperoleh jaminan bahwa pengelolaan proses telah dilakukan dengan benar dan memenuhi standar pengelolaan teknologi informasi yang baik.

Demikian halnya dengan domain ME, dimana dengan tingkat kematangan saat ini yang tertinggi ada pada proses ME1 dalam hal mengawasi dan mengevaluasi kinerja teknologi informasi dengan nilai tingkat kematangannya adalah 2,755. Hal ini dikarenakan pihak manajemen sudah mulai melakukan manajemen kinerja teknologi informasi yang efektif melalui proses pemantauan. Sudah 
memiliki proses dalam cakupan mendefinisikan indikator kinerja yang relevan namun masih bersifat menyeluruh. Pelaporan mengenai kinerja sudah dilakukan tetapi belum secara sistematis dan kadang cenderung belum dapat memenuhi waktu yang ditetapkan dan dalam menangani setiap penyimpangan belum secara cepat dapat dilaksanakan. Pemantauan masih dilaksanakan secara berkesinambungan sehingga belum dapat secara langsung memastikan kebenaran dari sebuah proses atau kegiatan dan sejalan dengan arah dan kebijakan yang telah ditetapkan.

Tingkat kematangan saat ini yang terendah dalam domain ME adalah pada proses ME4 yang mewakili proses menyediakan tata kelola teknologi informasi yaitu 2,535. Sebagai implikasinya, manajemen harus segera memperbaiki sistem bisnis pemasaran online karena belum memiliki suatu kerangka kerja tata kelola yang efektif dalam mendefinisikan struktur organisasi, proses, kepemimpinan, peran dan tanggung jawab untuk memastikan bahwa investasi teknologi informasi selaras dan dilakukan sesuai dengan strategi dan tujuannya. Nilai kesenjangan tercatat 0,465 sebagai selisih dari tingkat kematangan ke 3 (ditetapkan/defined). Hal ini menandakan terdapat sejumlah kesenjangan yang harus dihilangkan agar dapat mencapai tingkat kematangan yang diinginkan. Hasil penelitian memperlihatkan dari semua rincian proses tersebut memiliki tipe prioritas yang berbeda dari sisi kebutuhan untuk segera dilakukan perbaikan. Semua proses tata kelola teknologi informasi memperlihatkan semua proses yang ada perlu mendapat perhatian yang sama pentingnya. Namun demikian diantara semua proses tersebut terdapat proses ME4 yang harus memperoleh prioritas yang lebih penting. Selanjutnya untuk proses-proses yang merupakan prioritas untuk diperbaiki meliputi ME1, ME2, dan ME3.

Selain peningkatan proses, pihak manajemen perlu melakukan tindakan perbaikan terhadap ketidaksesuaian proses yang telah ada terhadap standar sehingga tidak akan terjadi hal serupa di masa mendatang. Oleh karena pentingnya peningkatan pengelolaan proses, kemampuan penentuan indikator pengukuran kinerja, dan pemahaman kondisi perusahaan-perusahaan bisnis pemasaran online melalui penentuan tingkat kematangan. Kondisi ini menjadi hal kritis dan harus dilakukan manajemen dalam perbaikan berkelanjutan. Keterlibatan antara pihak manajemen dengan pengguna dalam proses teknologi informasi untuk memastikan langkah yang diambil sesuai dengan kejadian aktual.

Adapun rekomendasi untuk kebutuhan domain AI terkait dengan objektif kontrol untuk proses AI4 yaitu memungkinkan operasional dan penggunaan dalam tata kelola tersebut terkait dengan objektif kontrol yang lain, dimana sebagai objektif kontrol input terdiri dari PO10 (mengelola proyek), AI1 (mengidentifikasi solusi otomatis), AI2 (memperoleh dan memelihara perangkat lunak aplikasi), AI3 (memperoleh dan memelihara infrastruktur teknologi informasi), AI7 (instalasi dan akreditasi solusi beserta perubahannya), DS7 (mendidik dan melatih pengguna), dan sebagai objektif kontrol output terdiri dari AI7 (instalasi dan akreditasi solusi beserta perubahannya), DS4 (memastikan layanan yang berkelanjutan), DS8 (mengelola service desk dan insiden), DS9 (mengelola konfigurasi), DS11 (mengelola data), dan DS13 (mengelola operasi). Semua proses ini untuk menghasilkan panduan-panduan administrasi, pengguna, operasional, support dan teknis.; DS7 (kebutuhan transfer pengetahuan untuk implementasi solusi), DS7 (materi pelatihan).

Sementara untuk rekomendasi tata kelola teknologi informasi yang berhubungan dengan objektif kontrol untuk proses ME4 yaitu menyediakan tata kelola teknologi informasi dalam tata kelola tersebut terkait dengan objektif kontrol yang lain dimana sebagai objektif kontrol input terdiri dari PO4 (mendefinisikan proses teknologi informasi, organisasi dan keterhubungannya), PO5 (mengelola investasi teknologi informasi), PO9 (menaksir dan mengelola resiko teknologi informasi), ME2 (mengawasi dan mengevaluasi kontrol internal), dan ME3 (memastikan pemenuhan terhadap kebutuhan eksternal) dan sebagai objektif kontrol output terdiri dari PO4 (peningkatan proses kerangka kerja); PO1 (mendefinisikan rencana strategis teknologi informasi) dan ME1 (mengawasi dan mengevaluasi kinerja teknologi informasi) untuk memenuhi laporan keadaan tata kelola teknologi informasi; PO5 (hasil bisnis yang diharapkan dari investasi bisnis dari kemampuan teknologi informasi); PO1 (pengarahan strategik perusahaan pada teknologi informasi); dan PO9 (selera perusahaan pada resiko teknologi informasi).

Gambar 4 dan 5 memperlihatkan model rekomendasi mengenai tata kelola teknologi informasi untuk proses AI4 dan ME4 adalah penting untuk menyelaraskan kebutuhan teknologi informasi dalam penggunaan media sosial agar dapat memperluas bisnis pemasaran online. Hubungan keterkaitan antar proses teknologi informasi untuk domain AI4 dan ME4 adalah wujud nyata dari 
perlunya proses sinkronisasi dan integrasi dalam memperbaiki aliran informasi baik dari sisi objektif kontrol input dan outputnya.

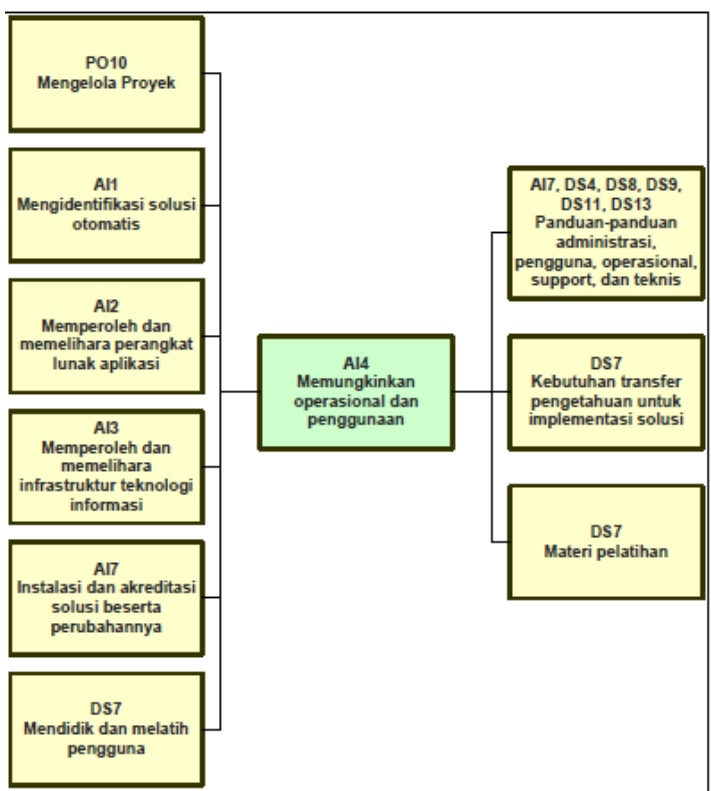

Gambar 4. Keterkaitan Proses AI4 Dengan Proses Lainnya

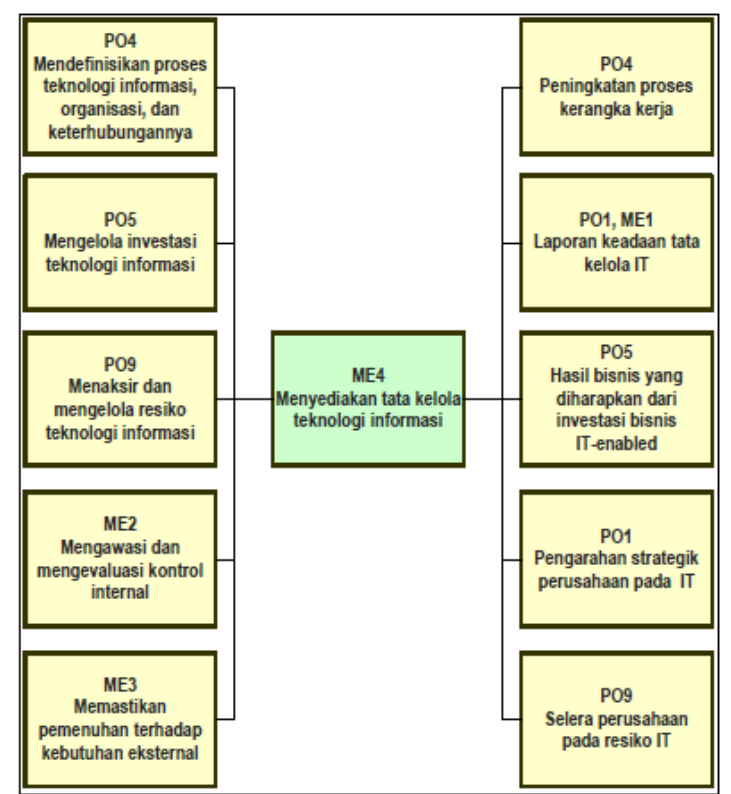

Gambar 5. Keterkaitan Proses ME4 Dengan Proses Lainnya

\section{KESIMPULAN}

Untuk meningkatkan tingkat kematangan khususnya pada AI4 (memungkinkan operasional dan pengguna), maka pimpinan dan manajemen perusahaan dalam menjalankan bisnis pemasaran online harus mengembangkan perencanaan dan dokumentasi yang jelas berisi semua dokumen teknis, kemampuan operasional dan semua jelas layanan yang diperlukan, melakukan transfer pengetahuan agar menjadi jelas mengenai kepemilikan sistem dan data/informasi sehingga dalam melakukan penyampaian layanan dan mutu, kontrol internal dan proses administrasi aplikasi menjadi lebih mudah untuk digunakan.

Sementara untuk meningkatkan tingkat kematangan khususnya pada ME4 (menyediakan tata kelola teknologi informasi), manajemen harus memiliki mekanisme dan prosedur yang tepat sasaran mengenai tata cara dan manajemen dalam kegiatan: kinerja teknologi informasi bisnis online harus memberikan transparansi dan memiliki pengelolaan biaya, keuntungan, strategi kebijakan dan level layanan teknologi informasi dengan ketentuan tata kelola; menjaga prestasi teknologi informasi dan diikuti dengan teknologi informasi yang berhubungan dengan hukum dan peraturan; memenuhi kepatuhan dengan hukum dan kebijakan; mengintegrasikan tata kelola teknologi informasi dan tata kelola kooperasi dan melengkapinya dengan hukum dan peraturan.

\section{SARAN}

Evaluasi tingkat kematangan harus diukur secara periodik dan tidak hanya domain AI dan ME. Pihak manajemen dan pemangku kepentingan juga perlu dilibatkan dalam mendalami setiap domain dan proses teknologi informasi. Evaluasi ini dapat dilanjutkan dengan menganalisa lebih mendalam dari masing-masing pelaku bisnis online. Hal ini penting mengingat dengan memiliki kesatuan informasi yang jelas dan terukur dari setiap domain akan mempermudah dalam perumusan dan perencanaan teknologi media sosial untuk mencapai tingkat kematangan teknologi informasi yang diharapkan. 


\section{UCAPAN TERIMA KASIH}

Penulis mengucapkan terima kasih kepada pihak manajemen Sekolah Tinggi Manajemen Informatika dan Komputer (STMIK) Pontianak yang telah memberikan dukungan dalam penelitian ini. Terima kasih juga kepada rekan-rekan dosen yang telah memberikan saran dan dukungan dalam menyelesaikan penelitian ini. Kepada para reviewer saya juga mengucapkan banyak terima kasih atas bimbingan dan arahannya untuk perbaikan penelitian ini sehingga menjadi lebih baik lagi.

\section{DAFTAR PUSTAKA}

[1] Davids, Z., \& Brown, I., 2014, Social Media Marketing Strategy in Organizations: A South African Case Study, Proceedings Annual Workshop of the AIS Special Interest Group for ICT in Global Development, hal 1-14.

[2] Recine, M., Prichard, J., \& Chaudhury, A., 2013, Social Media and Evolving Marketing Communication Using IT, Communications of the Association for Information Systems, Vol. 33, hal 115-128.

[3] Holland, Christopher P., 2015, Internet and Social Media Strategy in Sports Marketing, European Conference on Information Systems (ECIS), Münster, Germany, hal 1-16.

[4] Puskakom, 2015, Profil Pengguna Internet Indonesia 2014, Edisi Pertama, Penerbit Asosiasi Penyelenggara Jasa Internet Indonesia.

[5] Hasil Survei 2016, Penetrasi \& Perilaku Pengguna Internet Indonesia, Polling Indonesia dan Asosiasi Penyelenggara Jasa Internet Indonesia.

[6] Kaplan, A. M., \& Haenlein, M., 2010, Users Of The World, Unite! The Challenges And Opportunities Of Social Media, Business Horizons, Vol. 53, No. 1, hal 59-68.

[7] Neti, S., 2011, Social Media And Its Role In Marketing, International Journal Of Enterprise Computing And Business Systems, Vol. 1, No. 2, hal 1-15.

[8] Andzulis, J. M., Panagopoulos, N. G., \& Rapp, A., 2012, A Review Of Social Media And Implications For The Sales Process, Journal Of Personal Selling \& Sales Management, Vol. 32, No. 3, hal 305-316.

[9] Guesalaga, R., 2016, The Use Of Social Media In Sales: Individual And Organizational Antecedents, And The Role Of Customer Engagement In Social Media, Industrial Marketing Management, Vol. 54, hal 71-79.

[10] Mardi, M., Arief, M., Furinto, A., \& Kumaradjaja, R., 2016, Sustaining Organizational Performance Through Organizational Ambidexterity by Adapting Social Technology. Journal of the Knowledge Economy, hal 1-18.

[11] Holliman, G., \& Rowley, J., 2014, Business to Business Digital Content Marketing: Marketers' Perceptions of Best Practice, Journal of research in interactive marketing, Vol. 8, No. 4, hal 269-293.

[12] Berthon, P. R., Pitt, L. F., Plangger, K., \& Shapiro, D., 2012, Marketing Meets Web 2.0, Social Media, and Creative Consumers: Implications for International Marketing Strategy, Business Horizons, Elsevier, Vol. 55, pp. 261-271.

[13] Kietzmann, J. H., Hermkens, K., \& McCarthy, I. P., Silvestre, B. S., 2011, Social Media? Get Serious! Understanding the Functional Building Blocks of Social Media, Business Horizons, Elsevier, Vol. 54, hal 241-251, 2011.

[14] Bughin, J., \& Chui, M., 2013, Evolution Of The Networked Enterprise: McKinsey Global Survey Results, McKinsey Quarterly, hal 1-10.

[15] Kaplan, A. M., \& Haenlein, M., 2010, Users of the World, Unite! The Challenges Andopportunities of Social Media, Business Horizons, Vol. 53, No. 1, hal 59-68.

[16] Colliander, J., \& Dahlén, M., 2011, Following the Fashionable Friend: The power of Social Media, Journal of Advertising Research, Vol. 51, No. 1, hal 313-320.

[17] Tang, Q., Gu, B., \& Whinston, A. B., 2012, Content Contribution for Revenue Sharing and Reputation in Social Media: A Dynamic Structural Model, Journal of Management Information Systems, Vol. 29, No. 2, hal 41-76.

[18] Hanna, R., Rohm, A., \& Crittenden, V. L., 2011, We're All Connected: The Power of the Social Media Ecosystem, Business Horizons, Vol. 54, No. 3, hal 265-273. 
[19] Peters, L., 1998, The New Interactive Media: One-to-One, But Who to Whom? Marketing Intelligence \& Planning, Vol. 16, No. 1, hal 22-30.

[20] Mangold, W. G., \& Faulds, D. J., 2009, Social media: The New Hybrid Element of the Promotion Mix, Business Horizons, Vol. 52, No. 4, hal 357-365.

[21] Porter, C. E., \& Donthu, N., 2008, Cultivating Trust and Harvesting Value in Virtual Communities, Management Science, Vol. 54, No. 1, hal 113-128.

[22] Bonsón, E., \& Flores, F., 2011, Social Media and Corporate Dialogue: The Response of Global Financial Institutions, Online Information Review, Vol. 35, No. 1, hal 34-49.

[23] Peppler, K. A., \& Solomou, M., 2011, Building creativity: Collaborative learning andcreativity in social media environments. On the Horizon, 19(1), hal 13-23.

[24] Selig. G. J., 2015, Implementing Effective IT Governance and IT Management: A Practical Guide to World Class Current and Emerging Best Practices, Second Edition, Van Haren Publishing.

[25] Haes, D. S., \& Grembergen, W. V., 2015, Enterprise Governance of Information Technology: Achieving Alignment and Value, Featuring COBIT 5, Second Edition, CO Springer International Publishing Switzerland.

[26] Xu, Hongjiang., 2016, Benefits And Concerns Of Using Social Media-Users' Perspective, Proceedings of the Eleventh Midwest Association for Information Systems Conference, Milwaukee, Wisconsin, hal 1-5.

[27] Raisinghani, M., 2012, Social Media And E-commerce: A Strategic Perspective, Proceedings of the Eighteenth Americas Conference on Information Systems, Seattle, Washington, hal 1-16.

[28] Constantinides, E., 2014, Foundations of Social Media Marketing, Procedia-Social and behavioral sciences, hal 148, 40-57.

[29] Kosasi, S., \& Vedyanto, 2015, The Maturity Level of Information Technology Governance of Online Cosmetics Business, 3rd International Conference on New Media, IEEE, DOI: 10.1109/CONMEDIA.2015.7449140, hal 1-6.

[30] Kosasi, S., Yuliani, IDA Eka., Vedyanto., 2015, Evaluation of Maturity Level of E-Procurement Application Systems, Electrical Engineering Computer Science and Informatics (EECSI) Conference, hal 167-172.

[31] Brand, K., \& Bonnen, H., 2007, IT Governance Based on CoBiT 4.1-A Management Guide, Amersfoort NL.

[32] IT Governance Institute, 2007, COBIT 4.1: Framework, Objective Controls, Management Guidelines, Maturity Models, ISACA, ITGI. 